\title{
Superconducting Super Collider decision made at last
}

\section{Washington}

THE town of Waxahachie, 25 miles south of Dallas, Texas, was named last week as the intended home of the Superconducting Super Collider (SSC), the 52-milecircumference proton accelerator that the US Department of Energy (DoE) hopes to build. Secretary of Energy John Herrington's announcement officially ended eighteen months of fierce and expensive competition for the SSC between a number of states, but provoked a chorus of protests from the losers that the outcome had been politically rigged.

Since the selection of seven candidate sites from an initial entry of 43 late last year (see Nature 331, 2; 1988), a DoE task force has visited the sites, assessed geological, environmental and demographic data, heard testimony from the proponents and estimated for each location the 'lifecycle' cost of building the SSC and running

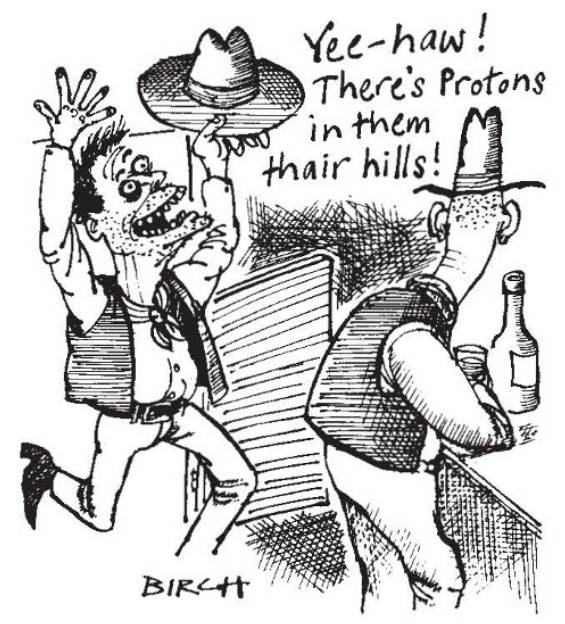

it for 25 years. Each site was rated under six general headings, the most important being its geological suitability for the tunnels that will house the main ring of magnets. The Texas site was deemed 'outstanding' in four of the six headings, and good in the other two, a ranking that put it clearly ahead of the other six proposals.

Immediate and vehement protest came from Senator Alan Dixon (Democrat) of Illinois, who called the choice "deeply disappointing" and implied that the announcement had been delayed until after the presidential election in order not to offend voters in Illinois. But Herrington said that representatives from all the seven states had asked him not to announce the decision until after the election, and that neither President Ronald Reagan nor President-elect George Bush was told of the outcome until election day.

The Illinois and Texas bids were generally thought to be the top contenders, but, according to the published account from the site selection task force, the Illinois proposal had one important failing. Adjoining the Fermi National Accelerator Laboratory, the SSC site goes under what is now a moderately urban area, and packets of land would have had to be obtained from over 3,000 individual land-owners.

The DoE task force was not convinced that the state would have been able to deliver the land to the federal government on schedule, especially as there was concerted local opposition to the SCC. This problem merited the only 'poor' rating handed out by the task force.

The advantage of Illinois, according to its supporters, was that Fermilab's Tevatron, a four-mile-long proton ring, could have been used as a feeder for the main SSC ring, eliminating a substantial fraction of the construction cost. But the life-cycle cost estimated by the task force was $\$ 10,400$ million, on the unproved assumption that the Tevatron could be plugged into the SSC with only minor changes, and rose to $\$ 10,900$ million if major changes were needed. By contrast,

\section{International Peace Week of Scientists}

\section{Washington}

Thanks to the United Nations, this year might be the last that the International Peace Week of Scientists passes unnoticed by most Western scientists. On 8 November, the UN Special Political Committee resolved that an 'International Week of Science and Peace' be proclaimed to take place each year during the week in which 11 November falls. Member states are urged to encourage scientific institutions to hold lectures and special activities on science and peace and to report to the UN Secretary General.

The resolution was introduced by Carlos Gutierrez, the Costa Rican Ambassador to the United Nations, on behalf of Costa Rica's president, Oscar Arias Sanchez. Final approval by the General Assembly is expected this month. UN action builds on an unofficial Science and Peace Week, now in its third year of operation, which was put together by Hendrik Bramhoff, a 33-yearold mathematician at the University of Hamburg in West Germany.

Bramhoff was inspired to set up the Science and Peace Week early in the 1980 s when he realized how important scientific opinion could be in arms negotiations, particularly on such technical issues as the policing of test-ban treaties. He found various activities already under way, many of them loosely centred on 11 November, Veteran's Day in the United States. He the cost at the Texas site was estimated at $\$ 10,800$ million.

Among the other sites, none had any serious disadvantages, but neither did they have the overall strengths of the Texas proposal. The Waxahachie site has easy access to the Dallas-Fort Worth metropolitan area, presents no special environmental problems, and the local community has supported the SSC bid.

Although Governor James Martin of North Carolina and Senator Dennis DeConcini of Arizona have indicated that they want to see some kind of inquiry into the site selection, they have not produced any specific objections to the technical ratings on which the choice was made. DoE will probably be able to defend itself against charges of political bias.

For Texas politicians, the selection of Waxahachie was cause for celebration. Among those attending the Herrington press conference were Jim Wright, Speaker of the House of Representatives, and Senators Lloyd Bentsen and Phil Gramm, along with two local congressmen. Texan George Bush announced his support for the project during the presidential campaign. All their efforts are likely to be needed if money to build the SSC is to be extracted from an increasingly parsimonious Congress. David Lindley helped to set up an International Coordinating Committee for Science and Peace Weeks held in 1986-88 and found backers for a UN resolution.

Bramhoff is now bowing out to concentrate on research and is passing leadership to David Krieger, president of a peace foundation based in Santa Barbara. Krieger inherits an organization whose biggest obstacle to growth may be its lack of international balance. In building up the Science and Peace Week, Bramhoff said he "worked with those willing to cooperate" and extended invitations to sponsor the week to many scientific organizations, both East and West.

The result is that Science and Peace Week is endorsed in the Eastern bloc by government-sponsored organizations such as the Hungarian Peace Council and the Soviet Peace Committee whereas in the United States and Europe it attracts the support of pressure groups critical of their governments. Bramhoff hopes that with UN support, Science and Peace Week will attract wider attention.

Armed with the resolution, researchers will have a better chance of persuading university presidents to back lectures and other activities. That, he says, is particularly important in developing countries where the links between science and peace have yet to be publicly debated.

Alun Anderson 